\title{
COVID-19 Pandemisi ve Diabetes Mellitus
}

\author{
Faruk KUTLUTÜRK ๑ ه \\ Tokat Gaziosmanpaşa Üniversitesi, Tıp Fakültesi, Endokrinoloji ve Metabolizma Hastalıkları Bilim Dalı, Tokat, Türkiye \\ Bu makaleye yapılacak atıf: Kutlutürk F. COVID-19 Pandemisi ve Diabetes Mellitus. Türk Diyab Obez 2020;2: 130-137.
}

\begin{abstract}
ÖZ
Coronavirüs ailesinden SARS-CoV-2'nin neden olduğu COVID-19 pandemisi, ilk olarak Çin'de görülen ve bulaşıcllı özelliği yüksek bir hastalıktır. Hastalığın mortalite ve morbiditesinde diyabet başta olmak üzere komorbid hastalıkların varlığı ve ileri yaş belirleyici olmaktadır. COVID-19 tarafından tetiklenen hücresel mekanizmalar ve diyabet patofizyolojisi, diyabetli bireyleri potansiyel organ hasarı ile sonuçlanacak bir sitokin fırtınasına daha duyarlı hale getirmektedir. COVID-19 ile infekte olmuş diyabetik hastalarda hastaneye başvuru, yatış oranları, şiddetli pnömoni gelişimi ve diğer komorbit hastalıklara göre daha yüksek mortalite oranlarının olduğu gösterilmiş̧tir. Bu risk, iyi glisemik kontrol ile tamamen ortadan kaldırlmasa da azaltılabilmektedir. Diyabetli hastalarda hem glisemik regülasyon hem de eşlik eden kalp hastalı̆̆ı, hipertansiyon, obezite veya böbrek hastalığı gibi komorbid durumların stabilizasyonu sağlanmalıdır.
\end{abstract}

Anahtar Sözcükler: Pandemi, Coronavirüs, SARS-CoV-2, COVID-19, Diabetes mellitus

\section{The COVID-19 Pandemic and Diabetes Mellitus}

\begin{abstract}
The COVID-19 pandemic, caused by SARS-CoV-2 of Coronaviruses types, is a highly infectious disease caused by SARS-CoV-2, which first appeared in China. The presence of comorbid diseases, especially diabetes, and advanced age are determinant for the mortality and morbidity of the disease. Considering the cellular mechanisms triggered by COVID-19 and the pathophysiology of diabetes, make individuals with diabetes more susceptible to a cytokine storm with potential organ damage. Studies have reported that individuals with diabetes and who have been infected by COVID-19 showed higher admission rates to hospitals, development of severe pneumonia as well as higher mortality rates, when compared to those without comorbidities. This risk can be reduced, though not completely eliminated, by good glycemic control. In patients with diabetes, both glycemic regulation and stabilization of comorbid conditions such as concomitant heart disease, hypertension, obesity or kidney disease should be provided.
\end{abstract}

Key Words: Pandemic, Coronavirus, SARS-CoV-2, COVID-19, Diabetes mellitus

\section{Gíriș}

Coronavirüs ailesinden akut respirutuvar sendromCoronavirüs-2 (SARS- CoV-2)'nin neden olduğu COVID-19 pandemisi, 2019 yılı sonlarında ilk olarak Çin Halk Cumhuriyet'inde ortaya çıkan bulaşıcılık özelliği yüksek bir hastalıktır. COVID-19 haftalar içinde neredeyse tüm ülkeleri etkilemiş ve Dünya Sağlık Örgütü tarafindan pandemi olarak ilan edilmiştir (1). Bir diğer küresel salgın olan Diabetes Mellitus, 2019 verilerine göre 20-79 yaş grubunda, dünya nüfusunun yaklaşı \%9.3'ünü etkileyen (463 milyon) kronik bir hastalıktır $(2,3)$. Ülkemizdeki veriler, diyabetli hasta sayısının on yılda ikiye katladığını ve diyabet prevalansının erişkinlerde 2010 yılında \%13.4 gibi çok önemli boyutlara ulaştığını göstermektedir (4). İki pandeminin bir arada olması (Dual pandemi), her iki pandemiden etkilenen çok sayıda hastanın olması ve bu 
hastalardaki kötü prognozla sonuçlanmaktadır (5). Bunu destekler nitelikte ilk veriler diyabetiklerde COVID-19 ile infekte olma ve şiddetli pnömoni gelişiminin diyabeti olmayanlara göre daha yüksek olduğu, dolayısıyla mortalite oranlarının da yüksek olduğu bildirilmiştir (6-9).

Etkenin izole edildiği Ocak-2020 tarihinden sonra, Türkiye de ilk vaka 11 Mart 2020'de rapor edilmiş, ülkemiz de bu pandeminin etkisi altına girmiş, diğer ülkelere göre daha başarılı bir pandemi yönetimiyle nispeten düșük mortalite oranları ile hastalık kontrol altında tutulabilmiştir (10). Yeni tanı konulan vakalar, yoğun bakımda yatan, entübe olan ve ölümle sonlanan vakaların sayıları ülkeden ülkeye değişmekte, bunda pandemi yönetiminde alınan tedbirler, ilaç kullanımındaki farklı algoritmaların benimsenmesi, entübasyon zamanlaması gibi birçok faktör etkili olmaktadır. Hastalığın mortalite ve morbiditesinde diyabet başta olmak üzere komorbit hastalıkların varlığı (hipertansiyon, obezite, immün sistemi etkileyen hastalık ve ilaçlar, kardiyovasküler hastalıklar.. vs) ve ileri yaş belirleyici olmaktadır $(5,6,11$ 14).

Çin Hastalık Kontrol ve Önleme Merkezi tarafından yayınlanan 72.314 COVID-19 vakası raporunda diyabetli kişilerde mortalitenin (\%7.3) diyabeti olmayanlara göre (\% 2.3) yaklaşı üç kat daha fazla olduğu gösterilmiştir (9). Plazma glukoz yüksekliği tek başına organ yetmezliği mortalite ve morbidite için risk faktörüdür. COVID19 'un eklenmiş etkisi diyabetlilerde organ hasarı için riski iyice artırmaktadır. Çin Halk Cumhuriyeti'nin değişik bölgelerinde COVID-19 hastalarındaki diyabet prevelansının \%7.4-20 arasında değişen yüksek değerlerde olduğu bildirilmiştir (8). İtalya'da hastaneye yatırılan COVID-19 hastalarında diyabet prevalansı $\% 8.9^{\prime}$ dur ve bu da İtalya'da 55-75 yaş aralığındaki diyabet prevalansının (\% 6.2) üstünde bir orandır (15).

\section{Diyabet ve COVID-19; Patofizyoloji}

Diyabetikhastalardaki patofizyolojik değişiklikler infeksiyon hastalıklarına yatkınlık yaratırken, diyabetik hastalarda oluşan herhangi bir infeksiyon da hiperglisemiye neden olmaktadır. Hangi tip diyabet olursa olsun infeksiyonlara ve bununla ilişkili komplikasyonlara yatkınlık artmaktadır. Kronik diyabet zemininde oluşan doğal immün cevabın disregülasyonu, endotel disfonksiyonu ve bozulmuş bariyer yapısı ile proinflamatuar hiperkoagulabiliteye, infeksiyonların oluşmasına ve daha ağır seyretmesine neden olmaktadır (16). Diyabet aynı zamanda proenflamatuar bir duruma neden olur. Nötrofil disfonksiyonu, azalmış T hücresi yanıtı ve düzensiz humoral bağışıklık nedeniyle diyabetiklerde bakteriyelve viral solunum yolu infeksiyonları özellikle yaygındır. Diyabetik hastalarda etkenden bağımsız olarak pnömoni artmış morbidite ve mortalite riski ile ilişkilidir (16).

Virüslerle mücadelede interferon cevabı çok önemlidir. COVID-19 hastalarında erken interferon cevapları baskılanmakta, ikincil ortaya çıkan maladaptif gecikmiş ve abartılı interferon cevabın sitokin firtınasına yol açarak organ hasarları oluşturmaktadır. Sitokin firtınasının tetiklediği bozulmuş endotel-epitel bariyer işlevleriyle birlikte mikrovasküler yataktaki hiperkoagulabilite hastalığın kötü prognozundan sorumlu olmaktadır $(6,17)$. COVID-19 tarafından tetiklenen hücresel mekanizmalarla diyabete özgü organlardaki patolojik değişiklikler biraraya geldiğinde, diyabetli bireylerde organ hasarı ile sonlanacak bir sitokin firtınası ihtimali katlanarak artmaktadır. COVID-19 ile infekte diyabetli bireylerde diyabetik olmayanlara göre interlökin-6 (IL-6), fibronojen, ferritin, D-dimer ve C-reaktif protein seviyeleri anlamlı derecede yüksek tespit edilmiştir (6). Özellikle, diyabet hastalarında, laktat dehidrojenaz (LDH), CRP, ferritin, D-dimer abartılı artışı, düşük lenfosit sayıları ve daha yaygın bilgisayar tomografi (BT) bulguları hastalığın kötü prognozunun bir göstergesidir (8).

Diyabet, obezite, hipertansiyon ve iskemik kalp hastalığı gibi komorbiditelerle birlikte var olan adiposit disfonksiyonu ve yüksek dereceli inflamasyon, COVID-19'da sitokin firtınasina sebep oluyor. Bu komorbiditelerden herbiri sitokin firtınası ile birlikte mortalitenin yüksek olmasından sorumlu olurken birarada bulunmaları durumunda mortalite oranları katlanarak artmaktadır.

Diyabetli bireylerde anjiyotensin dönüştürücü enzim 2 (ACE2) ekspresyonu azalmıştır. Bu enzim, akciğerler, pankreas, böbrekler, vasküler sistem ve bağırsak endotelini içeren birçok organda bulunan bir enzimdir. Normal fizyolojide, ACE2 antienflamasyon ve anti-oksidasyonda önemli bir rol oynar (6). Ancak diyabetik hastalarda bozulan bu fizyolojik durum COVID-19 ile infekte olunması durumunda akut solunum sikıntısı sendromu ('acute respiratory distress syndrome', ARDS) gibi ciddi akciğer hasarı riskini artırır (18).

ACE2'nin pankreasta da eksprese edildiği bilinmektedir. SARS ile ilgili daha önce yapılan araştırmalar Anjiotensin Converting Enzim 2 (ACE2)'ye bağlanarak akut hiperglisemiye neden olduğu ve bu durumunun mortalitede sorumlu olduğunu göstermiştir. $\mathrm{Bu}$ nedenle virüsün pankreatik adacıklara girişi, akut beta hücre işlev bozukluğuna yol açarak ortaya çıkan akut hiperglisemik duruma neden olabilir $(6,19)$. Aynı virüs ailesinden COVID-19'da da benzer durum söz konusu olabilir. ACE2 ekspresyonunun, ekzokrin pankreasın yanında pankreas adacıklarında da yoğun olduğu bildirilmiştir. Pankreas 
dokusuna penetre olan bu virüsün adacık harabiyeti yapması yüksek olasıdır. Daha önce SARS-CoV'nin pankreatik adacık hücrelerinde ACE2'ye bağlandığı, onlara zarar verdiği ve muhtemelen akut hiperglisemiye neden olduğu gösterilmiştir. Bu durum diyabeti olmayan kişilerde bile artmış mortaliteye katkıda bulunduğunu düşündürmektedir (19). Pankreas enzimlerinin de artması, bu virüsün sekonder DM yaptığını destekler bir bulgusu olarak değerlendirilmektedir $(17,20)$.

Guo ve ark. (6), 24 hastayı değerlendirdikleri çalışmalarında, diğer komorbiditeler mevcut olsun ya da olmasın, diyabet olmayan hastalara göre diyabetli SARS-CoV-2 pnömoni hastalarında, organ hasarı, enflamatuar faktörler veya hiperkoagulabilite açısından şiddetli bir klinik tablonun oluşarak prognozu kötüleştirdiğini bildirmiştir. Diyabetli kişilerin COVID-19 infeksiyonu için ve hastalıkla ilişkili tıbbi komplikasyonlar için yüksek risk altında olduğu aşikardır. $\mathrm{Bu}$ durum diyabetik hastalara yaklaşımda COVID-19 için tanı, tedavi ve takipte daha fazla hassas davranılması gerektiğini göstermektedir (21). Pandemi döneminde çok sayıda diyabet hastası diyabet kliniklerindeki rutin kontrollerini iptal etmek zorunda kalmıştır. Bu durum, sosyal izolasyon ve fiziksel aktivite eksikliği ile ilişkili artan stresle birlikte, diyabet hastalarını COVID-19 infeksiyonlarına daha da yatkın hâle getiren, glisemik ve kan basıncı kontrolünün kötüleşmesine yol açan zemin hazırlamıştır (21).

\section{Diyabet ve COVID-19; Hasta Yönetimi}

Diyabet hastalarının iyi bir glisemik kontrolü sürdürmeleri infeksiyon riskinin ve şiddetinin azaltılması için önemlidir. Hiperglisemi, kaynağı ne olursa olsun infeksiyonların kötü seyretmesi ve artmış mortalite ile ilişkilidir. İyi glisemik kontrol, bakteriyel süperinfeksiyonlara bağlı pnömoni olasılığını da azaltacaktır $(11,17)$. Diyabetli ve COVID$19^{\prime}$ lu hastaların optimal glisemik kontrolü riskleri tamamen ortadan kaldırmasa da azaltılabilir. Pandemik İnfluenza A (H1N1), SARS koronavirüsü ve MERSCoV Sendromu ile ilişkili koronavirüs infeksiyonlarının diyabetik bireylerde mortalite için önemli bir risk faktörü olduğu görülmüştür (22-25). Bu nedenle tüm diyabetiklere pnömokok ve yıllık grip aşıları önerilmektedir.

Yan ve ark. (7), COVID-19 tanılı 193 diyabet hastasının klinik özelliklerini inceledikleri çalışmalarında yoğun bakım ünitesine yatış, mekanik ventilasyon ve mortalitenin daha yüksek olduğunu tespit etmiştir. Diyabetli kötü prognozlu COVID-19 hastalarında abartılı inflamasyon yanıtı görüldüğünü ciddi COVID-19 hastalarında diyabetin ölüm için en önemli risk faktörlerinden biri olarak kabul edilmesi gerektiğini bildirmişlerdir (7). Kumar ve ark. (14), 33 çalışmayı inceledikleri metaanalizlerinde COVID-19 hastalarında altta yatan diyabet varlığının iki kat artmış mortalite riski ile ilişkili olduğunu belirlemişlerdir. Bu, diyabet hastalarında COVID-19'dan daha fazla korunmanın, COVID-19 tanısı alan diyabet hastalarında izlem, hastaneye yatış ve yoğun bakımda takip için daha erken davranılması gerekeceğini göstermektedir (14).

COVID-19 sürecinde diyabet hastalarının evde takip edilmesi, kan şekeri ölçüm sonuçlarının sağlık profesyonellerine iletilerek ilaç ve insülin dozlarının ayarlanması en ideal takip olacaktır. Hastalık sürecinde diyabetin sadece kan şekeri takibinden ibaret olmadığını, eşlik eden hastalıklar için ilgili branş hekimleriyle temasta olunması gerektiği hastaya hatırlatılmalıdır.

Hem diyabet hem de obezitenin bir sitokin firtınasına yol açacak mekanizmaları tetiklemesi nedeniyle, COVID-19 infeksiyonunun varlığ ile obez diyabetik hastalarda daha kötü bir enflamatuar etki ortaya çıkacaktır. Sitokin fırtınas1, insülin direncini artıracağından glisemik durum daha da kötüleşecektir (26). Obezite ayrıca artmış koagülopati ve tromboz ile ilişskilidir. Benzer şekilde, COVID-19 infeksiyonu da trombotik mekanizmalarla ve pıhtılaşma bozuklukları ile bağlantılıdır. Ayrıca COVID-19 ile infekte olmuş diyabetikler, diyabetik olmayanlara göre daha yüksek bir D-dimer seviyesine sahiptir. Bu nedenle, SARS-CoV-2 ile infekte olma durumunda, hem diyabet hem de obezite varlığ daha kötü bir prognoz ile ilişkilidir $(26,27)$. Cariou ve ark. (28), Coronado çalışmasında, vücut kütle indeksinin diyabetli popülasyonda COVID-19 şiddeti ve hastaneye yatış için bağımsız bir prognostik faktör olduğunu göstermiştir.

\section{Diyabet ve COVID-19; Tedavi- İlaç Seçimi}

COVID-19 ile infekte diyabet hastalarında klavuzlara giren tedavi algoritmaları henüz bulunmamaktadır. Uygun tıbbı beslenme alışkanlıklarının devam etmesi, egzersizin kısıtlandığ 1 bu dönemlerde vurgulanmalıdır. Egzersinin olumlu etkilerinden faydanılmaya devam edilmesi için ev şartlarına uygun egzersiz programları planlanmalıdır. Diyabetli bireyler psikolojik sıkıntıya, kaygıya ve depresyona eğilimlidir. Diyabetik hastalardaki bu eğilim, daha yüksek glikozile hemoglobin, daha yüksek vücut kütle indeksi, daha yüksek diyastolik kan basıncı ve düşük yoğunluklu kolesterol (LDL-C) gibi daha kötü bir metabolik profil ile ilişkilidir (17). Bunlar diyabetle ilgili komplikasyonlara katkıda bulunmaktadır. COVID-19 gibi stresli bir dönem, diyabetli bireylerin yaşam kalitesini düşürebilir ve glisemi yönetimini etkileyebilir (29). Bu nedenle, bu pandemi sırasında ek psikolojik yardım ve destek çok önemlidir.

COVID-19 infeksiyonun şiddeti ve evresi, diyabetle ilgili komorbiditeler ve kronik komplikasyonlar, diyabetin tipi, hastanın kronolojik yaşı ve diyabet süresi bu hastalara 
tedavide belirleyici olmaktadır $(1,10,11,17)$. COVID-19 virüsüne yönelik tedavi algoritmaları ülkeden ülkeye farklılıklar göstermekte, bazı ülkelerde ilerde yaşanacak olası yasal sorunlar nedeniyle, hikroksiklorokin (HCQ) gibi bazı ilaçların kullanımından imtina etmektedirler. Her ne kadar klorokin ve HCQ kanitı sinırlı olsa da, daha iyi bir geçerli tedavi seçeneği olmadığından klorokin ve HCQ'nun potansiyel olarak faydalı risk-denge dengesini göz önünde bulundurarak bu ilaçlar COVID-19 salgınında kullanılmaktadır. Diğer uygulanan tedavilere göre Klorokin ve HCQ'nun düşük maliyeti, COVID-19'a karşı özellikle daha yaygın kullanımına olanak sağlamaktadır (30). Hipoglisemi, klorokin/hidroksiklorokin tedavisinin bilinen bir yan etkisi olduğundan, diyabetli insanlar için güvenlik endişeleri vardır. Ancak bu ilaçların hipoglisemik etkilerinin zayıf olmasından dolayı hipoglisemiden çekinerek tedavi protokollerinde değişiklik yapılması önerilmemektedir (31).

\section{Metformin}

Metformin, tip 2 DM tedavisi için ilk basamak ilaçlardandır. Tarihsel olarak, metformin başlangıçta bir anti-influenza ilacı olarak üretilmiş, hipoglisemik etkisi anlaşılınca antidiyabetik olarak kullanılmaya başlanılmıştır (32). Metforminin AMP-Activated Protein Kinase (AMPK)'in metformin ile aktivasyonu, ACE2'nin fosforilasyonuna yol açar, bu da bu reseptörde fonksiyonel değişikliklerle sonuçlanır (33). Bu tür değişiklikler SARS-CoV-2'nin bağlanmasını azaltabilir (32). Bu nedenle, diyabetli bir kişi COVID-19 ile infekte olursa metformin alımı için herhangi bir kontrendikasyon olmadı ̆̆ı varsayılır. Hastalığın ileri dönemlerinde organ yetmezlikleri varlığında metformin kullanılmamalıdır.

\section{Thiazolidinedionlar}

Glitazonlar, etkisini Peroksizom Proliferatör-Aktive edici Reseptör-Gama (PPAR- $\gamma$ ) inhibisyonu ile gösterirler. Pioglitazonun, IL-6 salgılanması dahil proinflamatuar sitokinleri inhibe ettiği bildirilmiştir (34). Bu etki sonucunda diyabetik hastalarda inflamatuar süreç ve bununla ilişkili biyokimyasal belirteçlerin azaldığı gösterilmiştir. Bu nedenle, pioglitazon uygulamasının COVID-19 için destekleyici bir tedavi olabileceği varsayılmıştır (34). Glitazonların sulfonilüre grubu ilaçlara göre pnömoni riskini artırdığını gösteren çalışma bulunsa da bu konudaki kanitlar yorum yapmak için yetersizdir (35). Kalp yetmezliği olan, ödemi olan, insülin kullanan, COVID-19'un ileri safhalarında organ yetmezlikleri gelişen hastalarda kullanılmamalıdır.

\section{Sülfonilüre, Glinidler ve Alfa-glukosidaz inhibitörleri}

$\mathrm{Bu}$ grup ilaçlara özel bir öneri bulunmamakta, diyabeti regüle olan hafif COVID-19 hastalarında bulunacağ 1 belirtilmektedir. Var olan tedavi kesilerek insulin tedavisi verilmelidir (17). Uzun etkili sülfoniürelerde hipoglisemi riski göz önünde tutulmalıdır.

\section{Dipeptidil Peptidaz - 4 (DPP-4) inhibitörleri}

DPP4 enzimi, immün sistem hücreleri ve solunum sistemi dahil birçok organda bulunmaktadır $(36,37)$. Bu enzimin virüslerin hücre içine girmesinde bir rolü olduğunu düşündüren, DPP4 eksprese eden hayvan modellerinde MERS-CoV infeksiyonuna yatkınlık oluşturduğunu bildiren çalışmalar bulunmaktadır $(36,38)$. Bazı sitokinlerin (IFNalfa, beta ve gamma) DPP4 ekspresyonunu ve aktivitesini artırdığ 1 bilinmektedir. Deneysel modellerde DPP4 ekspresyonun artmasının insülin direnci ve hiperglisemiye yol açtığı gösterilmiştir (20). Dolayısıyla diyabetik zeminde olası yüksek DPP4 aktivite ve ekspresyonu, virüsün hem doku penetrasyonunu kolaylaştırıp sitokin fırtınasıyla sonuçlanan virulans artışına yolaçabilir $(12,17)$. DPP4 inhibitörlerinin üst solunum yolu infeksiyonu riskinde artışla ilişkilendiren çalışmalar olsa da bu ajanların artmış pnömoni için risk artışına yol açtığı gösterilememiştir $(35,39)$. COVID-19 ile infekte diyabetiklerde DPP4 inhibisyonun olumlu bir etkisi olduğunu gösteren çalışma bulunmadığından tedavi algoritmalarında bir değişiklik şu an için söz konusu olmamıştır.

\section{GLP-1 reseptör agonistleri}

Glukagon benzeri peptid 1 reseptör agonistlerinin deneysel hayvan modellerinde antienflamatuvar etki gösterdiği ve diyabetik modellerde kullanıldığında sistemik enflamasyon belirteçlerini azalttığg bildirilmektedir (40,41). Sepsis ve kritik hastalıklarda hastalığın şiddeti ile orantılı olarak dolaşımdaki GLP-1 düzeyleri artar. GLP-1R agonistleri ile yapılan büyük kardiyovasküler güvenlik çalısmalarında inflamatuar hastalıklarda ve ciddi infeksiyonlarda artış gözlenmemiştir. GLP-1R agonistlerinin perioperatif dönemde ve yoğun bakımda yatan hastalarda kullanıldığg çalışmalarda genel olarak güvenli ve glisemi regülasyonunda etkili olduğu bulunmuş ve böbrek fonksiyonlarında kötüleşme olmadıkça kullanımına devam edilebilceği belirtilmiştir (42). Ancak yoğun bakım şartları için hâlen öncelikli olarak insülin tedavisi tercih edilmelidir. Yeni COVID-19 tanısı alan hastalarda hastalık kliniğini ve takibini güçleştireceğinden GLP-1R agonisti tedavisi başlanması önerilmemektedir.

\section{Sodyum Lukoz Transporter-2 (SGLT-2) İnhibitörleri}

Ayaktan tedavi edilen hastalarda SGLT2 inhibitörleri iyi tolere edilse de, COVID-19 infeksiyonu olan hastalarda anoreksi, dehidratasyon klinik durumda ani bozulmalar görülebilmesi nedeniyle semptomatik tip 2 DM'li hastalarda 
önerilmemektedir. Tip 2 diyabetli olup COVID-19 tanıs1 alan ayaktan/evde SGLT2 inhibitörü kullanan hastalarda tedavinin gözden geçirilmesi, yatan ve orta-ciddi infeksiyonu olan hastalarda ise kesilmesi önerilmektedir. SGLT2 inhibitör tedavisi alan COVID-19 tanılı hastalar infeksiyonun başlangıcından itibaren öglisemik ketoasidoz, hipovolemi, elektrolit bozuklukları ve renal fonksiyonlar açısından takip altında tutulmalıdır $(17,43)$.

\section{İnsülin}

Diyabetli COVID-19 hastalarından genel durumları iyi ve kan glukozu regüle olan hastalar eski aldıkları tedaviye devam edebilirler ancak genel durum kötüleşmesi, hipergliseminin kontrol edilememesi, yoğun bakım yatışı yapılan hastalarda insulin tedavisine geçilmelidir. COVID19 'da hangi insülin tedavi protokolü uygulanırsa uygulansın hipoglisemiden kaçınılması gereklidir.

\section{Antihipertansif ve Statinler}

Hipertansiyon ile ilgili COVID-19'un hücre zarındaki ACE2 reseptörüne tutunarak hücre içine girdiği bilgisi, ACE inhibisyonu ile etki gösteren antihipertansiflerin patogenezde rol oynayabileceğini düşündürmüştür (18, 42). ACE2 reseptör blokerlerinin ACE2 reseptörlerini artırdığının ileri sürülmesine rağmen, kanıtlar yeterli değildir. ACE inhibitörlerinin coronavirüsün hücre içine girişini kolaylaştırdığına dair ispat edilmiş bir bilgi yoktur. Viral pnömonilerde ACE inhibitörleri ve statinlerin mortaliteyi azalttığına dair bilgiler olsa da kanıt düzeyleri düşüktür $(17,44)$. Güncel veriler, statin ve $\mathrm{ACE}$ inhibitörüne bağlı bir yan etki olmayan hastaların ilaçlarını kullanmaya devam etmeleri gerektiğini göstermektedir.

\section{Diyabet ve COVID-19; Yoğun Bakım Yönetimi}

Hiperglisemi, yoğun bakım hastalarında sık karşılaşılan bir durumdur. Hiperglisemi, hastanın daha önceden bilinen veya henüz tanı konulmamış diyabetine bağlı olabileceği gibi, yoğun bakım hastalarında stres, steroid kullanımı, vazopressör ilaç kullanımı, enteral ve parenteral nütrisyonlar veya glukoz içeren sıvı infüzyonları, uzun süreli yatak istirahati gibi faktörlerle de gelişebilmektedir. Yoğun bakım hastalarında, mortalite ve morbidite ile hiperglisemi arasındaki ilişki olduğu birçok çalışmada gösterilmiştir (45, 46). COVID-19 hastaları ile yapılan bir çalışmada diyabetli hastalar diyabeti olmayanlarla karşılaştırıldığında: bu hastalarda daha fazla yoğun bakım yatışı (\%22,2'ye karşı \%5,9) ve mekanik ventilasyon ihtiyaçları olmuş, hastanede kalış süresi ve mortalite daha yüksek tespit edilmiştir $(45,46)$.

Diyabet, şiddetli pnömoni gelişimi ve septik seyir için birincil risk faktörüdür. Diyabetli COVID-19 hastaları hızla ARDS ve septik şoka ilerleyebilir ve çoklu organ yetmezlikleri gelişebilir. Yaş ve eşlik eden komorbiditeler, COVID-19'lu hastalarda artmış mortalite için risk faktörleri olarak kabul edilmektedir (8). Çin'deki COVID-19 mortalite vakaları ile ilişkili majör komorbiditeler; hipertansiyon $(\% 53,8)$, diabetes mellitus (\%42,3), kalp hastalı̆̆ $(\% 19,2)$ ve serebral enfarktüs $(\%$ 15,4). Diyabetli hastalarda, mortalite diyabeti olmayanlara göre \%50 daha fazla tespit edilmiştir $(47,48)$.

Yoğun bakım hastalarında (kritik hastalarda) kan glukozu $180 \mathrm{mg} / \mathrm{dL}$ üzerinde ise hedefkan glukoz değerlerine ulaşmak için insülin infüzyonu başlanmalı ve kan glukoz değerleri 140-180 mg/dL arasında tutulmalıdır. Seçilmiş hastalarda 110-140 mg/dL gibi daha sıkı hedefler benimsenebilir (17, 45, 46, 49). Kritik hastalarda hiperglisemi yönetimi için ideal bir protokol yoktur. Uygun bir protokol hastanın klinik durumuna ve esnek kan şekeri hedeflerine göre düzenlenmelidir (45).

Yoğun bakım ünitesine kabul edilen kritik hastalarda hiperglisemi tehlikelidir ve tedavi edilmelidir, ancak tedavi sırasında gelişen hipoglisemi de mortal seyredebilmektedir. Hipoglisemi hem diyabetik hem diyabeti olmayanlarda mortalite ve morbiditeyi artırmaktadır.

Kritik hastalarda hiperglisemi yönetiminde en güvenli ve etkili yöntem sürekli intravenöz insülin infüzyonudur. İnsülin infüzyonu yapılan hastalarda başta potasyum olmak üzere elektrolit kontrolü/replasmanı sıklıkla yapılmalıdır (11, 50). Diyabetik COVID-19 hastalarının yoğun bakım ünitelerinde glisemi takipleri saatlik yapılmalı ve insülin infüzyon hızı ayarlanmalıdır. Eğer hastada şok durumu varsa, vazopressör tedavi aliyorsa ve ciddi periferal ödem varsa parmak ucu kapiller kan glukoz ölçümü yerine arteriyel veya venöz tam kan örneği alınmalıdır. Hastaların genel durumu düzeldikten sonra glisemik kontrolün sürdürülmesi önemlidir. Hastalarda oral alımı kısıtlayacak işlem planlanıyorsa, periferik ödem çözülmemişse, vazopressör kullanımı devam ediyorsa subkutan insülin tedavisine geçiş ertelenmelidir $(17,47,48)$.

\section{Diyabet ve COVID-19; Ketoasidoz}

Diyabetik ketoasidoz (DKA) ve COVID-19 ilişkili sınırlı sayıda veri bulunmaktadır $(51,52)$. COVID-19 virüsünün spike proteini yardımıyla tutunduğu fonksiyonel ACE2 reseptörleri, akciğer ve başka birçok organın yanında, pankreas endokrin adacıklarda dayoğun miktarda tespitedilmiştir (19). ACE2 akciğerlerde, pankreasta yüksek oranda eksprese edilir ve SARS-CoV-2 için giriş noktası olarak işlev görür (53). RAAS'ta anahtar bir enzim olan anjiyotensin dönüştürücü enzim 2 (ACE2), anjiyotensin II'nin anjiyotensine dönüşümünü katalizler (53). COVID-19'da olası ketoasidoz nedenleri olarak SARS-CoV-2'nin pankreatik adacık hücrelerine girişi ile direkt olarak beta hücre hasarı 
yapması ve virüsün hücre içine girişini takiben ACE2'nin 'down'-regülasyonu sonucu artan anijotensin-II'nin insülin sekresyonunu azaltması olduğu düşünülmektedir $(19,53)$. $\mathrm{Bu}$ durum beta hücre fonksiyonlarının akut olarak azalmasına yol açarak ketoasidozun ortaya çıkmasından sorumlu olabilir. Diyabetik ketoasidoz tedavi protokolleri diyabetik COVID-19 hastaları için de geçerlidir. COVID-19 tarafından tetiklenen ketoasidoz vakalarını takip ederken aşırı sıvı yükünden kaçınmak ve serum potasyum düzeylerini yakından takip etmek önemlidir (17).

\section{SONUÇ ve ÖNERILER}

Diyabet hastalarında COVID-19 infeksiyonu artmıș mortalite ile ilişkilidir. Diyabetli hastalarda hem glisemik regülasyon hem de eşlik eden kalp hastalığı veya böbrek hastalığı gibi komorbit durumların stabilizasyonu sağlanmalıdır. Diyabet hastaları ve özellikle komorbiditesi olan kişiler, COVID-19 infeksiyonu için sosyal izolasyon ve diğer önleyici tedbirlere uymaları konusunda uyarılmalıdır. Hastalar hiperglisemi riskinden haberdar olmalı ve ilaç doz değişiklikleri konusunda bilgilendirilmelidir. Diabetologlar, beslenme uzmanları ile disiplinlerarası danışmanlık da dahil olmak üzere uzaktan (internet ve web tabanlı, online) takip sistemleri düzenlemelidir.

Beslenmeye dikkat edilmesi ve yeterli protein alımı önemlidir. Herhangi bir mineral ve vitamin eksikliği varsa giderilmelidir. Egzersizin bağışıklığı geliştirdiği gösterilmiştir. Ancak spor salonu veya yüzme havuzları gibi kalabalık yerlerden kaçınmak gereklidir. Hastalığın sık görüldüğü bölgelere zorunlu olmayan seyahatlerden kaçınılmalıdır. Tip 1 diyabetli hastalarda hiperglisemi gelişirse idrar keton ölçümleri yapmalıdır. Dehidrate bırakacak anti-hiperglisemik ajanları kullanırken dikkat edilmeli veya hipoglisemiden kaçınılmalıdır. Organ yetmezlikleri gelişen hastalarda ilaçlar tekrar düzenlenmeli, metformin, SGLT2 inhibitörü kullanıyorsa kesilmelidir. İnsülin, hastanede yatan hastalar için hipergliseminin kontrolünde tercih edilen ajan olmalıdır.

\section{Etik Kurul Onayı}

Deneysel veya insan materyali kullanılmadığından Etik Kurul oluru bulunmamaktadir.

\section{Çıkar Çatışması}

$\mathrm{Bu}$ yazı için herhangi bir çıkar çatışması yoktur.

Finansal Destek

Herhangi bir finans desteği alınmamıştır.

Yazarların Makaleye Katkı Beyanı

Fikir, kaynak derleme, eleştirel yaklaşım ve yazım tamamen yazara aittir.

\section{KAYNAKLAR}

1. World Health Organization Coronavirus (COVID-19) Situtiation Report -114. 13 May 2020. (Erişim tarihi: 25.05.2020, https://apps.who.int/iris/handle/10665/332089).

2. Cuschieri S, Grech S. COVID-19 and diabetes: The why, the what and the how. J Diabetes Complications. 2020;107637

3. Saeedi P, Petersohn I, Salpea P, et al. Global and regional diabetes prevalence estimates for 2019 and projections for 2030 and 2045: Results from the International Diabetes Federation Diabetes Atlas, $9^{\text {th }}$ edition. Diabetes Res Clin Pract. 2019;157:107843.

4. Satman I, Omer B, Tutuncu Y, et al. Twelve-year trends in the prevalence and risk factors of diabetes and prediabetes in Turkish adults. Eur J Epidemiol. 2013;28(2):169-180.

5. Maddaloni E, Buzzetti R. Covid-19 and diabetes mellitus: Unveiling the interaction of two pandemics. Diabetes Metab Res Rev. 2020;e33213321.

6. Guo W, Li M, Dong Y, et al. Diabetes is a risk factor for the progression and prognosis of COVID-19. Diabetes Metab Res Rev. 2020;e3319.

7. Yan Y, Yang Y, Wang F, et al. Clinical characteristics and outcomes of patients with severe covid-19 with diabetes. BMJ Open Diabetes Res Care. 2020;8(1):e001343.

8. Guan WJ, Ni ZY, Hu Y, et al. Clinical Characteristics of Coronavirus Disease 2019 in China. N Engl J Med. 2020;382(18):1708-1720.

9. Wu Z, McGoogan JM. Characteristics of and Important Lessons From the Coronavirus Disease 2019 (COVID-19) Outbreak in China: Summary of a Report of 72314 Cases From the Chinese Center for Disease Control and Prevention. JAMA. 2020;10.1001/jama.2020.2648. doi:10.1001/jama.2020.2648.

10. T.C. Saglık Bakanlığı, Halk Sağlığı Genel Müdürlüğü COVID-19 (SARS-CoV-2 infeksiyonu) Rehberi, Bilim Kurulu Çalışması. 14 Nisan 2020, Ankara.

11. Katulanda P, Dissanayake HA, Ranathunga I, et al. Prevention and management of COVID-19 among patients with diabetes: An appraisal of the literature. Diabetologia. 2020;1-13.

12. Hussain A, Bhowmik B, do Vale Moreira NC. COVID-19 and diabetes: Knowledge in progress. Diabetes Res Clin Pract. 2020;162:108142.

13. Grasselli G, Zangrillo A, Zanella A, et al. Baseline Characteristics and Outcomes of 1591 Patients Infected With SARS-CoV-2 Admitted to ICUs of the Lombardy Region, Italy. JAMA. 2020;323(16):1574-1581.

14. Kumar A, Arora A, Sharma P, et al. Is diabetes mellitus associated with mortality and severity of COVID-19? A metaanalysis. Diabetes Metab Syndr. 2020;14(4):535-545.

15. Fadini GP, Morieri ML, Longato E, Avogaro A. Prevalence and impact of diabetes among people infected with SARSCoV-2. J Endocrinol Invest. 2020;43(6):867-869

16. Kornum JB, Thomsen RW, Riis A, Lervang HH, Schonheyder HC, Sorensen HT. Type 2 diabetes and pneumonia outcomes: A population-based cohort study. Diabetes Care. 2007;30(9):2251-2257. 
17. COVID-19 Pandemi diyabet izlem ve tedavi kriterleri uzlaşı raporu. Türk Diyabet Vakfı, Mayıs 2020.

18. Pal R, Bhansali A. COVID-19, diabetes mellitus and ACE2: The conundrum. Diabetes Res Clin Pract. 2020;162:108132.

19. Yang JK, Lin SS, Ji XJ, Guo LM. Binding of SARS coronavirus to its receptor damages islets and causes acute diabetes. Acta Diabetol. 2009;47(3):193-199.

20. Drucker DJ. Coronavirus Infections and Type 2 DiabetesShared Pathways with Therapeutic Implications. Endocr Rev. 2020;41(3):bnaa011.

21. Hill MA, Mantzoros C, Sowers JR. Commentary: COVID-19 in patients with diabetes. Metabolism. 2020;107:154217.

22. Meo SA, Alhowikan AM, Al-Khlaiwi T, Meo IM, Halepoto DM, Iqbal M, et al. Novel coronavirus 2019-nCoV: Prevalence, biological and clinical characteristics comparison with SARS-CoV and MERS-CoV. Eur Rev Med Pharmacol Sci. 2020;24(4):2012-9.

23. Yang JK1, Feng Y, Yuan MY, Yuan SY, Fu HJ, Wu BY, et al. Plasma glucose levels and diabetes are independent predictors for mortality and morbidity in patients with SARS. Diabet Med. 2006;23(6):623e8.

24. Schoen K, Horvat N, Guerreiro NFC, de Castro I, de Giassi KS. Spectrum of clinical and radiographic findings in patients with diagnosis of $\mathrm{H} 1 \mathrm{~N} 1$ and correlation with clinical severity. BMC Infect Dis. 2019;19(1):964.

25. Song Z, Xu Y, Bao L, et al. From SARS to MERS, Thrusting Coronaviruses into the Spotlight. Viruses. 2019;11(1):59.

26. Kassir R. Risk of COVID-19 for patients with obesity. Obes Rev. 2020;21(6):e13034.

27. Kaye SM, Pietiläinen KH, Kotronen A, Joutsi-Korhonen L, Kaprio J, Yki-Järvinen $\mathrm{H}$,et al. Obesity-related derangements of coagulation and fibrinolysis: A study of obesity- discordant monozygotic twin pairs. Obesity. 2012;20:88-94.

28. Cariou, B., Hadjadj, S., Wargny, M. et al. Phenotypic characteristics and prognosis of inpatients with COVID-19 and diabetes: The CORONADO study. Diabetologia. 2020;63(8):1500-1515.

29. Mukhtar S, Mukhtar S. Mental health and psychological distress in people with diabetes during COVID-19. Metabolism. 2020;108:154248.

30. Singh AK, Singh A, Shaikh A, Singh R, Misra A. Chloroquine and hydroxychloroquine in the treatment of COVID-19 with or without diabetes: A systematic search and a narrative review with a special reference to India and other developing countries. Diabetes Metab Syndr. 2020;14(3):241-246.

31. Cansu DU, Korkmaz C. Hypoglycaemia induced by hydroxychloroquine in a non-diabetic patient treated for RA. Rheumatology (Oxford). 2008;47(3):378-379.

32. Amin S, Lux A, O'Callaghan F. The journey of metformin from glycaemic control to mTOR inhibition and the suppression of tumour growth. Br J Clin Pharmacol. 2019;85:37-46.

33. Plattner F, Bibb JA. Serine and threonine phosphorylation. Basic Neurochem. 2012:467-492.
34. Carboni E, Carta AR, Carboni E. Can pioglitazone be potentially useful therapeutically. in treating patients with COVID-19? Med Hypotheses. 2020;140:109776.

35. Gorricho J, Garj_on J, Alonso A, Celaya MC, et al. Use of oral antidiabetic agents and risk of community-acquired pneumonia: A nested case-control study. Br J Clin Pharmacol. 2017;83(9):2034-2044.

36. Raj VS, Mou H, Smits SL, et al. Dipeptidyl peptidase 4 is a functional receptor for the emerging human coronavirusEMC. Nature. 2013;495:251-254.

37. Reinhold D, Biton A, Goihl A, et al. Dual inhibition of dipeptidyl petidase IV and aminopeptidase $\mathrm{N}$ suppresses inflammatory immune responses. Ann N Y Acad Sci. 2007;1110:402-409.

38. Bloomgarden ZT. Diabetes and COVID-19. Diabetes. 2020:347-348.

39. Iacobellis G. COVID-19 and diabetes: Can DPP4 inhibition play a role? Diabetes Res Clin Pract. 2020;162:108125.

40. Bloodworth MH, Rusznak M, Pfister CC, et al. Glucagon-like peptide 1 receptor signaling attenuates respiratory syncytial virus-induced type 2 responses and immunopathology. J Allergy Clin Immunol. 2018;142(2):683-687.e12.

41. Toki S, Goleniewska K, Reiss S, et al. Glucagon-like peptide 1 signaling inhibits allergen-induced lung IL-33 release and reduces group 2 innate lymphoid cell cytokine production in vivo. J Allergy Clin Immunol. 2018;142(5):1515-1528.e8.

42. Bornstein SR, Rubino F, Khunti K, et al. Practical recommendations for the management of diabetes in patients with COVID-19. Lancet Diabetes Endocrinol. 2020;8(6):546-550.

43. Gajjar K, Luthra P. Euglycemic Diabetic Ketoacidosis in the Setting of SGLT2 Inhibitor Use and Hypertriglyceridemia: A Case Report and Review of Literature. Cureus. 2019;11(4):e4384.

44. Henry C, Zaizafoun M, Stock E, et al. Impact of angiotensinconverting enzyme inhibitors and statins on viral pneumonia. Proc (Bayl Univ Med Cent). 2018;31(4):419-423.

45. Kar P, Jones KL, Horowitz M, et al. Management of critically ill patients with type 2 diabetes: The need for personalised therapy. World J Diabetes. 2015;6(5):693-706.

46. Wang W, Lu J, Gu W, et al. Care for diabetes with COVID-19: Advice from China. J Diabetes. 2020;12(5):417-419.

47. Gupta R, Ghosh A, Singh AK, Misra A. Clinical considerations for diabetes in times of COVID-19 epidemic. Diabetes Metab Syndr. 2020;14(3):211-212.

48. Deng SQ, Peng HJ. Characteristics of and Public Health Responses to the Coronavirus Disease 2019 Outbreak in China. J Clin Med. 2020;9:575.

49. Bode B, Garrett V, Messler J, et al. Glycemic Characteristics and Clinical Outcomes of COVID-19 Patients Hospitalized in the United States. J Diabetes Sci Technol. 2020;1932296820924469.

50. Peric S, Stulnig TM. Diabetes and COVID-19: DiseaseManagement-People. Wien Klin Wochenschr. 2020;1-6. 
51. Chee YJ, Ng SJH, Yeoh E. Diabetic ketoacidosis precipitated by Covid-19 in a patient with newly diagnosed diabetes mellitus. Diabetes Res Clin Pract. 2020;164:108166.

52. Li J, Wang X, Chen J, Zuo X, Zhang H, Deng A. COVID-19 infection may cause ketosis and ketoacidosis. Diabetes Obes Metab. 2020;10.1111/dom.14057.
53. Bornstein SR, Dalan R, Hopkins D, Mingrone G, Boehm BO. Endocrine and metabolic link to coronavirus infection. Nat Rev Endocrinol. 2020;16(6):297-298. 